\title{
A model of service-learning implementation: case of Ukrainian Catholic University
}

\author{
Y. Kleban, Y. Kokoiachuk, I. Krynytska \\ Ukrainian Catholic University, Ukraine
}

\begin{abstract}
Service-learning $(\mathrm{SL})$ is a relatively new approach for the Ukrainian education system. The Ukrainian Catholic University (UCU) became the first in Ukraine to introduce it at the institutional level. The organization of this process requires a transparent methodology and algorithm for implementation. In this study, we consider the institutional performance of SL at UCU from the standpoint of innovation management in the educational process. The paper's objective is to describe the SL model implementation at the UCU based on the analysis of the carried-out optimizing processes. The classic problem-based approach with interactive research and designbased research were applied to develop the model. Furthermore, the description of the results uses a process-oriented methodology as the most appropriate for the current and future research work. The success of the SL approach implementation is partly due to the technical part by which it is about the design of the work process and the internal culture of the HEI. The groups of stakeholders involved in designing and adopting the SL model and pedagogy are foundational in the applied case of the process-oriented methodology. The final goal was to identify the areas with the most significant opportunities for improvement when implementing $S L$ in the HEI. The model of implementation of SL in the HEI, presented in this study, was created on the business process mapping principles and can be valuable for other educational institutions that want to implement this approach.
\end{abstract}

\section{Keywords}

Algorithm of implementation, business process mapping, process thinking, Honda philosophy, analytics.

Fecha de recepción: 24/XI/2021

Fecha de aceptación: 9/XII/2021

Kleban, Y., Kokoiachuk, Y. y Krynytska, I. (2021). A model of service-learning implementation: case of Ukrainian Catholic University. RIDAS, Revista Iberoamericana de Aprendizaje Servicio, 12, 115-124.

DOI10.1344/RIDAS2021.12.12 


\title{
Un modelo de implementación de aprendizaje-servicio: el caso de la Universidad Católica de Ucrania
}

\begin{abstract}
Resumen
El aprendizaje-servicio (ApS) es un enfoque relativamente nuevo para el sistema educativo ucraniano. La Universidad Católica de Ucrania (UCU) se convirtió en la primera en Ucrania en introducirlo a nivel institucional. La organización de este proceso requiere una metodología y un algoritmo transparentes para su implementación. En este estudio, consideramos el desempeño institucional del ApS en la UCU desde el punto de vista de la gestión de la innovación en el proceso educativo. El objetivo del trabajo es describir la implementación del modelo ApS en la UCU a partir del análisis de los procesos de optimización llevados a cabo. Se aplicó el enfoque clásico basado en problemas con investigación interactiva e investigación basada en diseño para desarrollar el modelo. Además, la descripción de los resultados utiliza la metodología orientada a procesos como la más adecuada para el trabajo de investigación. El éxito de la implementación del enfoque ApS se debe en parte a la parte técnica por la cual se trata del diseño del proceso de trabajo y la cultura interna de la UCU. Los grupos de actores involucrados en el diseño y adopción del modelo y la pedagogía de ApS son fundamentales en el caso aplicado de la metodología orientada a procesos. El objetivo final fue identificar las áreas con mayores oportunidades de mejora a la hora de implementar ApS en las universidades. El modelo de implementación de ApS, presentado en este estudio, fue creado sobre los principios del mapeo de procesos de negocios y puede ser valioso para otras instituciones educativas que quieran implementar este enfoque.
\end{abstract}

\section{Palabras clave}

Algoritmo de implementación, mapeo de procesos de negocio, pensamiento de procesos, analítica. 


\title{
Un model d'aplicació d'aprenentatge servei: el cas de la Universitat Catòlica d'Ucraïna
}

\begin{abstract}
Resum
L'aprenentatge servei (ApS) és un enfocament relativament nou per al sistema educatiu ucraïnès. La Universitat Catòlica d'Ucraïna (UCU) es va convertir en la primera a Ucraïna a introduir-la a nivell institucional. L'organització d'aquest procés requereix una metodologia i un algorisme transparents per a la seva implementació. En aquest estudi considerem el rendiment institucional de I'ApS a la UCU des del punt de vista de la gestió de la innovació en el procés educatiu. L'objectiu del treball és descriure la implementació del model ApS a la UCU a partir de l'anàlisi dels processos d'optimització realitzats. Per desenvolupar el model es va aplicar l'enfocament clàssic basat en problemes amb investigació interactiva i recerca basada en el disseny. A més, la descripció dels resultats utilitza la metodologia orientada a processos com la més adequada per al treball de recerca actual i futur. L'èxit de la implementació de l'enfocament ApS es deu en part a la part tècnica per la qual es tracta del disseny del procés de treball i de la cultura interna de I'UCU. Els grups d'actors implicats en el disseny i l'adopció del model i la pedagogia d'ApS són fonamentals en el cas aplicat de la metodologia orientada a processos. L'objectiu final va ser identificar les àrees amb oportunitats de millora més significatives a I'hora d'implantar ApS. El model d'implantació de l'ApS, presentat en aquest estudi, es va crear sobre els principis de mapeig de processos empresarials i pot ser valuós per a altres institucions educatives que vulguin implementar aquest enfocament.
\end{abstract}

\section{Paraules clau}

Algoritme d'implementació, mapeig de processos de negoci, pensament de processos, anàlisi. 


\section{Introduction}

The education system today needs new approaches to work with students. Due to the development of technologies, constant fluidity, variability of the environment, learning today requires testing the maximum involvement of experience. Thus, the learning process should include tools that help students acquire academic knowledge by consolidating it into practical experience.

Traditionally, universities have two primary missions - education and research. They are the basis of processes and institutional development engines, allowing you to track work results. However, in recent years, another mission of universities has been to contribute to the development of society - called the "Third mission." The "third mission" was assigned to Molas-Gallart (as cited in Gregorová et al., 2020, p.12) as "... generation, use, application and use of knowledge and other opportunities of the university outside the academic environment". Today the service-learning pedagogical approach implements this training through experience.

The concept of service-learning originated in the 70s of the twentieth century. One of its founders is A. Furco stresses gaining academic experience combined with practice, bringing public benefit. The methodology of service learning is to develop such an approach to learning. Students gain knowledge and apply it in practice through socially valuable activities for a particular

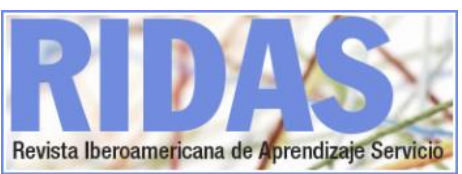

group, community, etc.

Today, the international community identifies service training on three critical grounds:

- Focus on effectively meeting the needs of the community, and not just the community.

- Active involvement of pupils/students in all stages, from planning to evaluation.

- Relationship to learning content (Learning, reflection, community development skills, research) (Regina, 2017).

Service-learning allows one to determine the necessary vector of practical activities through which students can consolidate or test academic knowledge. In implementing this approach, students, teachers, and the community are active participants. They interact all during the implementation of the educational component. Thus, the main activities are involvement of stakeholders and active participation in students' assignment planning, their constant reflection, and interaction with stakeholders accompanied by a teacher. Implementing the task aimed at the real needs of the community distinguishes the service-learning approach among other approaches.

\section{Methodology}

The research of several authors discusses service-learning, e.g., Furco, Heffernan, Lascell, Gaona, Staib De Chanes, Perold, Gregorová, Bariaková \& 
Regina. They considered and described the methodology and experience in service-learning. This approach is new for Ukraine.

The purpose of this article is to describe the implemented experience of servicelearning at the institutional level. The goal is to collect and share the Ukrainian Catholic University (UCU) case highlighting the most challenging steps.

The institutional implementation of the service-learning at the UCU should be considered from the standpoint of the opportunity and responsibility to become the first university to implement this innovation in the Ukrainian educational environment. Based on the interpretations of Hidalgo and Albors (2008), innovation can be considered as an interactive problemsolving process, including a diversified learning process, that arises from learning-by-using, learning-by-doing, or learning-by-sharing.

Both external and internal environments affect the implementation of the innovation. A crucial role is played by cooperating top management attitudes, marketing and information technology departments, and the organization's employees.

Interactive research is an exciting method to address the dual challenges of developing long-term strategies, innovations, and organizational change processes. The feature of the interactive study focuses on continuous collaborative learning processes between researchers and practitioners involved.
Another approach that includes researchers and practitioners systematically analyzing, designing, and evaluating educational innovations and interventions to address complex, real-world academic problems is design-based research (Ford et al., 2017). Design-based research is an adaptive approach because it involves the development of several stages of design development and testing. It is based on problem identification, assessment in a particular educational environment while implementing and evaluating specific changes.

From the business-oriented perspective, a process mindset is an approach that is core for evaluation purposes and improvement goals. The process mapping as the methodology has provided authors the background for identifying the steps, activities, potential risks, and additional room for improvement.

\section{Results and discussion}

Given the peculiarities of Interactive research and design-based research, in implementing service-learning in UCU, special attention was on a systematic approach and balanced planned work of the team. To effectively implement the service-learning approach, it is necessary to study the experience of implementing service learning in universities of different countries, as the organizational structure, system, and strategies to learning are different.

The implementation and institutionalization of the approach should occur at all university levels, including optimizing the academic 
component and other processes. The results can be improved by developing a motivation system to implement service-learning projects for all participants, highlighting the positive practices of project implementation. In each case, a specific project can be improved after testing, taking into account the views of all stakeholders. During this process, it is essential to adapt and agree on the conceptual framework, the relevant terms, which will be convenient and acceptable for projects in each country.

Organizational aspects are the outcome of the authors of the manual Teacher Training in Service-learning. Handbook for trainers, and which are confirmed by their own experience of institutionalization of service-learning include the following items:

- constant advising and mentoring on project implementation that involves developing a network of such mentors;

- creating a network of like-minded colleagues and students, receiving support from their departments/institutions during the creation and implementation of the service-learning course;

- taking into account the possibility of changing the curriculum/study program;

- development of cooperation with partners create a database of potential partners from the stakeholder environment;

- constant development and support of the idea;

- continuous reflection and analysis of potential risks during project implementation, etc.

To share our experience with others and see a general idea correctly, consider service-learning implementation from the point of view of processes.

Generally speaking, a process can be defined as a business's steps to create value for customers. The processoriented approach is about changing the mindset to the final customer's results rather than a set of duties.

Understanding the importance of the service-learning institutionalization process, the authors have decided to apply the process approach to systematize the obtained results. The process approach makes one think of the set of inputs (people, technology, and information) in an activity that will get you to the (expected) outcomes (outputs). Process thinking changes how one sets up the three elements, executes the activities, and analyzes the gained value. This methodology helps to adopt continuous improvement goals that are on the radar for UCU. Process thinking provides an organization to define the effectiveness and efficiency sides that leads to value creation for the main stakeholders.

The success of the service-learning approach implementation is partly due to the technical part by which it is about the design of the work process and the internal culture of the HEI. We have applied ad hoc the Honda philosophy (Miller, n.d.) of being on the spot and seeing the problem inside the

Kleban, Y., Kokoiachuk, Y. y Krynytska, I. (2021). A model of service-learning implementation: case of Ukrainian Catholic University. RIDAS, Revista Iberoamericana de Aprendizaje Servicio, 12, $115-124$. DOI10.1344/RIDAS2021.12.12 
working team, which helped increase the chances of solving the real problem while practicing the service-learning approach. Partly that became possible due to the broad mentoring activities. That helped the Task Force Team to combine in a proper proportion the socalled technical side, the working process design, and the foundational catholic culture within the university. By being with their colleagues on the main steps of designing the service-learning courses or/and projects, the obtained results cover the teacher's context, personal needs and provide more support style guidance than just using the predesigned frameworks or templates.

Based on the book 'Improving Business Processes' (Harvard Business Review, 2010), a matrix to analyze processes can be completed on the one hand in terms of inputs, activities, and outputs. The other point of view is a set of events, each of which combines people, technology, and information. By this combination, as presented in Table 1 , one may understand the potential steps and the appropriate resources while designing service-learning activities on the institutional level at a higher education institution.

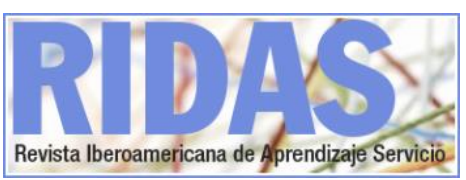

Table 1 . Key elements of the service-learning implementation processes

\begin{tabular}{|c|c|c|c|}
\hline $\begin{array}{l}\text { Steps/ } \\
\text { Resources }\end{array}$ & People & Technology & Information \\
\hline Inputs & $\begin{array}{l}\text { Task Force } \\
\text { Team } \\
\text { CLAYSS } \\
\text { UCU Faculty }\end{array}$ & $\begin{array}{l}\text { European } \\
\text { Toolkits }\end{array}$ & $\begin{array}{l}\text { External } \\
\text { resources of } \\
\text { other countries } \\
\text { experience }\end{array}$ \\
\hline \multicolumn{4}{|l|}{ Activities } \\
\hline $\begin{array}{l}\text { Work } \\
\text { Meetings }\end{array}$ & $\begin{array}{l}\text { Task Force } \\
\text { Team, UCU } \\
\text { administra- } \\
\text { tion }\end{array}$ & $\begin{array}{l}\text { Discussion } \\
\text { session, } \\
\text { meetings } \\
\text { agenda }\end{array}$ & $\begin{array}{l}\text { Internal } \\
\text { emailing } \\
\text { messages }\end{array}$ \\
\hline $\begin{array}{l}\text { Internal } \\
\text { Analysis of } \\
\text { UCU } \\
\text { experience }\end{array}$ & $\begin{array}{l}\text { Task Force } \\
\text { Team, } \\
\text { academic } \\
\text { programs } \\
\text { representa- } \\
\text { tives }\end{array}$ & Surveys & $\begin{array}{l}\text { Database on } \\
\text { proto service- } \\
\text { learning } \\
\text { activities at } \\
\text { UCU }\end{array}$ \\
\hline Open events & $\begin{array}{l}\text { Task Force } \\
\text { Team, } \\
\text { speakers, } \\
\text { Faculty, } \\
\text { school } \\
\text { teachers, } \\
\text { UCU } \\
\text { employees, } \\
\text { students, } \\
\text { community } \\
\text { organizations }\end{array}$ & $\begin{array}{l}\text { Presentations, } \\
\text { panel } \\
\text { discussions }\end{array}$ & $\begin{array}{l}\text { Presentations, } \\
\text { internal and } \\
\text { external } \\
\text { messaging } \\
\text { communication, } \\
\text { videos }\end{array}$ \\
\hline $\begin{array}{l}\text { Service- } \\
\text { learning } \\
\text { promotion }\end{array}$ & $\begin{array}{l}\text { Task Force } \\
\text { Team, } \\
\text { department } \\
\text { of } \\
\text { information, } \\
\text { UCU } \\
\text { administra- } \\
\text { tion }\end{array}$ & $\begin{array}{l}\text { Publications on } \\
\text { UCU website } \\
\text { etc., posts on } \\
\text { social media, } \\
\text { video creation } \\
\text { and sharing, } \\
\text { corporate } \\
\text { mailing, UCU's } \\
\text { projects on the } \\
\text { map of service- } \\
\text { learning in } \\
\text { Europe, World }\end{array}$ & $\begin{array}{l} \\
\text { Presentations, } \\
\text { internal and } \\
\text { external } \\
\text { messaging } \\
\text { communication, } \\
\text { videos }\end{array}$ \\
\hline $\begin{array}{l}\text { External } \\
\text { online } \\
\text { courses }\end{array}$ & $\begin{array}{l}\text { Trainers, } \\
\text { mentors, } \\
\text { teachers }\end{array}$ & $\begin{array}{l}\text { Lectures, } \\
\text { practical } \\
\text { sessions, } \\
\text { mentoring } \\
\text { hours }\end{array}$ & $\begin{array}{l}\text { Lecture } \\
\text { materials, brief } \\
\text { case studies }\end{array}$ \\
\hline $\begin{array}{l}\text { Service- } \\
\text { learning } \\
\text { Toolkit book }\end{array}$ & $\begin{array}{l}\text { Task Force } \\
\text { Team }\end{array}$ & $\begin{array}{l}\text { Regular team } \\
\text { meetings, } \\
\text { academic } \\
\text { writing, } \\
\text { brainstorming }\end{array}$ & $\begin{array}{l}\text { Materials of } \\
\text { Clayss, Furco, } \\
\text { etc. adapted for } \\
\text { UCU }\end{array}$ \\
\hline
\end{tabular}




\begin{tabular}{|c|c|c|c|}
\hline $\begin{array}{l}\text { Trainings/ } \\
\text { Workshops }\end{array}$ & $\begin{array}{l}\text { Trainers, } \\
\text { teachers, } \\
\text { mentors }\end{array}$ & $\begin{array}{l}\text { Presentations, } \\
\text { conversations, } \\
\text { discussions, } \\
\text { dynamic } \\
\text { networks }\end{array}$ & $\begin{array}{l}\text { Lectures, } \\
\text { presentations, } \\
\text { forms for } \\
\text { dynamic } \\
\text { networks, } \\
\text { forms for } \\
\text { projects }\end{array}$ \\
\hline $\begin{array}{l}\text { Personal } \\
\text { consultations } \\
\text { for academic } \\
\text { programs }\end{array}$ & $\begin{array}{l}\text { Trainers, } \\
\text { teachers, } \\
\text { academic } \\
\text { directors }\end{array}$ & $\begin{array}{l}\text { Conversations, } \\
\text { discussions, } \\
\text { design- } \\
\text { thinking, } \\
\text { brainstorming }\end{array}$ & $\begin{array}{l}\text { Academic } \\
\text { programs, list } \\
\text { of academic } \\
\text { courses, } \\
\text { syllabuses }\end{array}$ \\
\hline $\begin{array}{l}\text { The pilot- } \\
\text { project } \\
\text { development }\end{array}$ & $\begin{array}{l}\text { Teachers, } \\
\text { students, } \\
\text { community }\end{array}$ & $\begin{array}{l}\text { Brainstorming, } \\
\text { asset-mapping }\end{array}$ & Course syllabus \\
\hline $\begin{array}{l}\text { Service- } \\
\text { learning } \\
\text { projects } \\
\text { implementa- } \\
\text { tion }\end{array}$ & $\begin{array}{l}\text { Teachers, } \\
\text { students, } \\
\text { community }\end{array}$ & & $\begin{array}{l}\text { Service- } \\
\text { learning Toolkit } \\
\text { book, } \\
\text { syllabuses }\end{array}$ \\
\hline $\begin{array}{l}\text { Grant } \\
\text { applications } \\
\text { development } \\
\text { and } \\
\text { submission }\end{array}$ & $\begin{array}{l}\text { Task Force } \\
\text { Team, } \\
\text { Development } \\
\text { office }\end{array}$ & & $\begin{array}{l}\text { Grant } \\
\text { announcements } \\
\text {, requirements }\end{array}$ \\
\hline $\begin{array}{l}\text { Participation } \\
\text { in } \\
\text { conferences, } \\
\text { development } \\
\text { of scientific } \\
\text { articles } \\
\end{array}$ & $\begin{array}{l}\text { Task Force } \\
\text { Team }\end{array}$ & $\begin{array}{l}\text { Presentation, } \\
\text { speech, } \\
\text { academic } \\
\text { writing }\end{array}$ & Speech, article \\
\hline $\begin{array}{l}\text { Research and } \\
\text { analysis of } \\
\text { service- } \\
\text { learning } \\
\text { projects } \\
\text { implementa- } \\
\text { tion }\end{array}$ & $\begin{array}{l}\text { Task Force } \\
\text { Team, } \\
\text { administra- } \\
\text { tion, } \\
\text { teachers, } \\
\text { students }\end{array}$ & $\begin{array}{l}\text { Focus groups. } \\
\text { questionnaire, } \\
\text { discussions }\end{array}$ & Database \\
\hline Outputs & $\begin{array}{l}\text { About } 60 \\
\text { teachers } \\
\text { completed } \\
\text { workshops } \\
\text { and training } \\
\text { Students } \\
\text { completed } \\
13 \text { service- } \\
\text { learning } \\
\text { courses/proje } \\
\text { cts }\end{array}$ & $\begin{array}{l}\text { Service- } \\
\text { learning Toolkit } \\
\text { book tested }\end{array}$ & $\begin{array}{l}\text { Service- } \\
\text { learning } \\
\text { projects' results } \\
\text { data for } \\
\text { evaluation }\end{array}$ \\
\hline
\end{tabular}

Source: own elaboration

The general purpose of the business process is to bring together the mission, goals, and corresponding measures of the value performance delivered to the final customer. Here we share the data about the servicelearning implementation mission at UCU, which is about realizing the "University that serves". The purpose was stated as each alumnus should have experience in the service-learning course within the study program in the next five years. That requirement involves having a set of service-learning courses at each bachelor and master program.

The groups of stakeholders involved in designing and adopting the servicelearning model and pedagogy are foundational in the applied case of the process-oriented methodology. The presented mapping does not distinguish between formal and informal ones. Generally speaking, most o rules, technologies, and documents result from ongoing informal processes. The and guidance were firstly informal while adopting the UCU's context. Later, after a probation period, the toolkit and the strategic goals of service-learning at the HEI helped to transform to the formal stage. This stage is still under construction while the service-learning Resource Center will start working.

The business process mapping (BPM) adapted to the HEI helped authors distinguish the exact process, team, information, perform analysis and find room for improvement. Those steps are followed by the data collection phases, making it possible to incorporate the analytics approach. The model of the central business processes concerning the main stakeholders is in Figure 1. 
Figure 1. A model of service-learning implementation
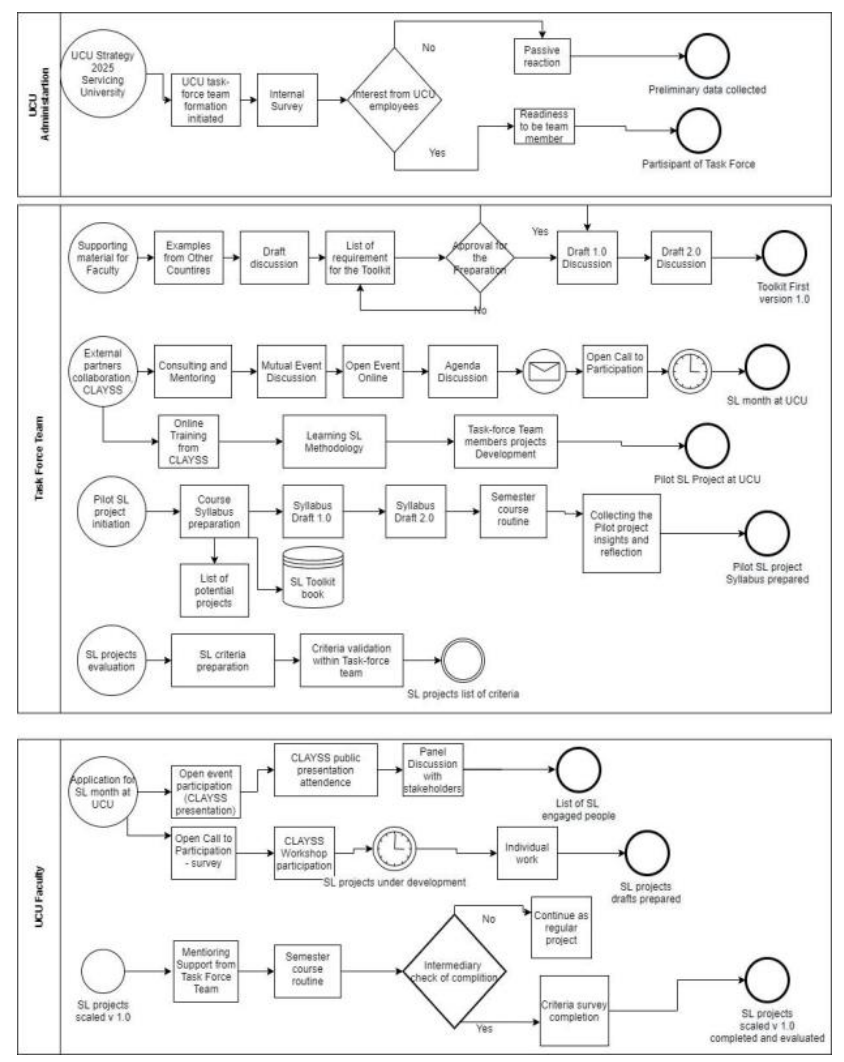

Source: own elaboration

Careful planning is required to avoid risks, ensuring flexibility of processes, constant monitoring, and reflection on project implementation, not only in individual cases but also at the institutional level, as process optimization will provide flexibility in project schedule and results. Taking into account the experience of other universities will help identify several scenarios of project development. Avoiding risks will enable a detailed preliminary study of community needs and the actual situation, affecting the project's outcome and analytics.
The implementation phase will require the identification of institutional alliances, the provision of resources, cooperation, and project management in conjunction with the development of learning content. Ongoing evaluation and reflection on each implementation stage and analysis of the achieved steps will help reduce other risks and adjust the project implementation.

Further prospects. The model of implementing service-learning in higher education is a result of this study and uses the principles of business processes mindset and may be valuable for other educational institutions that want to implement this approach.

Developed methodological materials, experience service-learning implementation at the institutional level, training and mentors will help other educational institutions implement and implement projects. Stakeholder reflection will serve to motivate the development of such projects at different levels of the educational process. We consider the preparation of a roadmap for implementing the approach and the implementation of specific projects, evaluating the quality of research and the peculiarities of building partnerships, as further prospects and next steps in work on this area.

\section{References}

Ford, C., McNally, D., \& Ford, K. (2017). Using Design-Based Research in Higher 
Education Innovation. Online Learning, 21(3), 50-67.

http://dx.doi.org/10.24059/olj.v21i3.12

$\underline{32}$

Gregorová, A., Matulayová, T., Tkadlcíková, L., Vodsedalek, V., Rusu, A., Costea-Bărluțiu, C., Pausits, A., Reisky, F., Ilic, B., Jelenc, L., Sporer, T., Husterer, I., Svidronová, M., Kubealaková, M., Bariaková, Z., Šolcová, J., Nemcová, L., Heinzová, Z., \& Rovnanová, L. (2020). ServiceLearning for Teachers in Higher Education Institutions. Matej Bel University Press

https://www.researchgate.net/publicati on/345179107 Teacher Training in Se rvice-Learning Manual for trainers

Hidalgo, A., \& Albors, J. (2008). Innovation management techniques and tools: a review from theory and practice. R\&D Management, 38(2), 113127. https://doi.org/10.1111/j.14679310.2008.00503.x

Harvard Business Review. (2010). Improving Business Processes (Pocket Mentor). Harvard Business Review Press.

Miller, L. (n.d.). The Honda way: a visit to Marysville.

https://www.Immiller.com/wpcontent/uploads/2011/06/The-HondaWay.pdf

Regina, C. (2017). Service-learning in Central and Eastern Europe handbook for engaged teachers and students.

Centro Latinoamericano de Aprendizaje y Servicio Solidario (CLAYSS). https://www.clayss.org.ar/04 publicaci ones/SL-EE nov17.pdf

Kleban, Y., Kokoiachuk, Y. y Krynytska, I. (2021). A model of service-learning implementation: case of Ukrainian Catholic University. RIDAS, Revista Iberoamericana de Aprendizaje Servicio, 12, $115-124$. DOI10.1344/RIDAS2021.12.12 